\title{
STUDIES ON NORTH AMERICAN CARBONIFEROUS INSECTS. 7. THE STRUCTURE AND RELATIONSHIPS OF EUBLEPTUS DANIELSI (PALAEODICTYOPTERA)*
}

\author{
By Frank M. Carpenter \\ Museum of Comparative Zoology \\ Harvard University, Cambridge, Mass. 02138
}

Eubleptus danielsi was described by Handlirsch in 1906 from a single, poorly preserved specimen in a concretion from the Francis Creek Shale, Illinois (Middle Pennsylvanian). The systematic position of the insect has been controversial. It was placed by Handlirsch in a new family, Eubleptidae, in the order Palaeodictyoptera. However, Martynov, in 1938, expressed doubt about its assignment to that order, and in 1952 Laurentiaux transferred it to a new order, Eubleptidodea, which Rohdendorf accepted in the Osnovy Paleontologii in 1962. Neither Laurentiaux nor Rohdendorf gave a diagnosis of the new order, although vague reference was made to the presence of large eyes and to the absence of pronotal lobes. From my study of the reverse half of the holotype (all that is now known) I came to the tentative conclusion (1965) that the insect was a member of the Palaeodictyoptera, probably related to the family Spilapteridae.

During the past decade, many additional specimens of Eubleptus have been found in a strip-mine pit on the Will-Kankakee County line, Illinois, mostly by private collectors. These new specimens, some of which are exceptionally well preserved, have been loaned to me for study. The purpose of this paper is to present the results of my examination of these specimens and to discuss the relationships of the insect, as it is now known.

I am grateful to Mr. Frederick J. Collier of the Department of Paleobiology, National Museum of Natural History, Washington, for the loan of the holotype of Eubleptus danielsi; and to Mrs. J.S. Lawless of the Peabody Museum of Natural History, Yale University, for the loan of the holotype of Athymodictya parva, a synonym

\footnotetext{
* Partial financial support of this research is gratefully acknowledged to the National Science Foundation, Grant No. DEB 82 05398, F.M. Carpenter, principal investigator.
} 
of danielsi. I am especially grateful to the following private collectors for the opportunity of studying their specimens: Mr. Paul Harris, now of Mountain Home, Arkansas; Helen and Ted Piecko, Chicago; Mr. and Mrs. Francis Wolff, now of Port Charlotte, Florida; Mr. Daniel Damrow, Mosinee, Wisconsin; Mr. Raymond Bandringa, Willow Brook, Illinois; Mr. Joseph Pohl, Belgium, Wisconsin; and Mr. Richard Rock, Crest Hill, Illinois. As will become apparent from the account below, our present extensive knowledge of Eubleptus has resulted mainly from their fossil collecting and their cooperation in making the specimens available for study.

I am deeply indebted to the late Dr. Eugene S. Richardson, Jr., formerly of the Department of Geology, Field Museum of Natural History, for his unfailing cooperation and his assistance over the past fifteen years in the course of our investigations on the insects in the concretions from the Francis Creek Shale.1

\section{Order Palaeodictyoptera}

\section{Family Eubleptidae Handlirsch}

Eubleptidae Handlirsch, 1906a, p. 679; 1906b, p. 111.2

Eubleptidae Laurentiaux, 1953, p. 423.

Eubleptidae, Carpenter, 1965, p. 178.

Small species, with slender, pointed wings. Fore wing; SC extending nearly to wing apex, terminating on the costal margin; RS dichotomously forked, with 4 (rarely 5 ) terminal branches; $M$ forking just basad of the origin of RS; MA with a long fork; MP with 3 terminal branches; CUA with a short fork; CUP with 3 (rarely 2) terminal branches; 3 short anal veins present; relatively few cross veins, unbranched, and forming a distinct pattern; archedictyon absent. Hind wing: similar to the fore wing in venation but slightly broader near or before mid-wing, the hind margin strongly curved. Body: moderately slender; antennae very long and thin; head apparently

'Shortly before his death in January, 1983, Dr. Richardson and I completed a joint paper on the Archaeognatha (Insecta) in the concretions. This will be published in the next issue of Psyche.

2The family, genus, and species were described and designated as new in both of Handlirsch's 1906 publications; the 1906a article obviously has priority, since many of its pages are cited by number in the $1906 \mathrm{~b}$ work. 


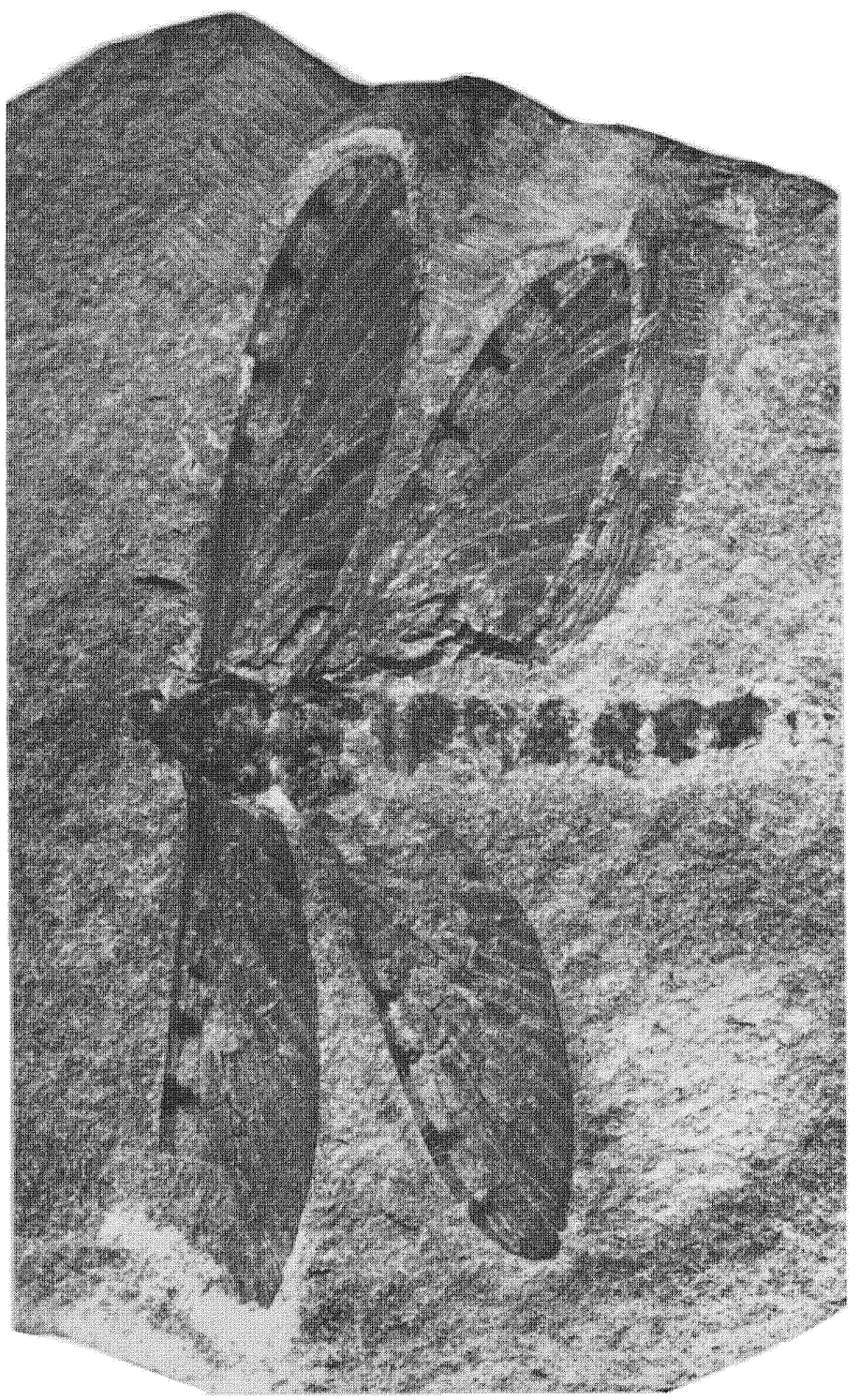

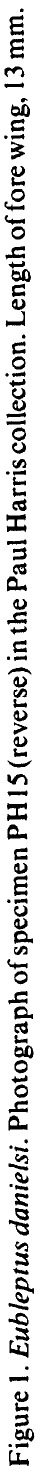


small in dorso-ventral view, but eyes prominent and protuding; beak well developed; prothorax short, with small and weak pronotal lobes; mesothorax and metathorax subequal; abdominal segments apparently with small lateral lobes; cerci very long; female with short, curved ovipositor.

The family is known only from the Francis Creek Shale.

\section{Genus Eubleptus Handlirsch}

Eubleptus Handlirsch, 1906a, p. 681; 1906b,p. 111.

Athymodictya Handlirsch, 1911, p. 298. NEW SYNONYMY.

Fork of MA at nearly the same level as the first fork of RS; first fork of MP well before mid-wing, its posterior branch forked near the wing margin.

Type-species: Eubleptus danielsi Handlirsch; by monotypy.

\section{Eubleptus danielsi Handlirsch}

Figures 1-8

Eubleptus danielsi Handlirsch, 1906a:681; 1906b:112; 1920:137. Rohdendorf, 1962:

54. Carpenter, 1965: 180.

Athy'modictya parva Handlirsch,1911:298. NEW SYNONYMY.

Fore wing: length 13-14 mm; maximum width, 3.5-3.8 $\mathrm{mm}$; hind wing: length $13-14 \mathrm{~mm}$; maximum width, $4-4.3 \mathrm{~mm}$; length of antennae (complete), $11 \mathrm{~mm}$. The venational pattern is shown in figure 2. Only slight individual variations seem to occur: RS usually with four terminal branches, but a fifth, short branch may be present; CUP usually with three branches, though the shortest one may be absent. Head about $3 \mathrm{~mm}$ wide across the eyes, and about 1.5 $\mathrm{mm}$ long as seen from above (i.e., not including the beak, which is 3 $\mathrm{mm}$ long). Pronotum about $1 \mathrm{~mm}$ long and 2.5 to $3 \mathrm{~mm}$ wide, including the small pronotal lobes; meso- and metathoracic segments apparently subequal, although the compression of the body has probably altered the true proportions of both segments; the abdomen is about $13 \mathrm{~mm}$ long and $2 \mathrm{~mm}$ wide at mid-length.

Holotype: no. 38731, U.S. National Museum of Natural History, Washington (L.E. Daniels, collector). This is a poorly preserved specimen, showing the proximal three-fourths of a fore wing and very little of the hind wings and body. Handlirsch described the species from both obverse and reverse halves, but when I examined 

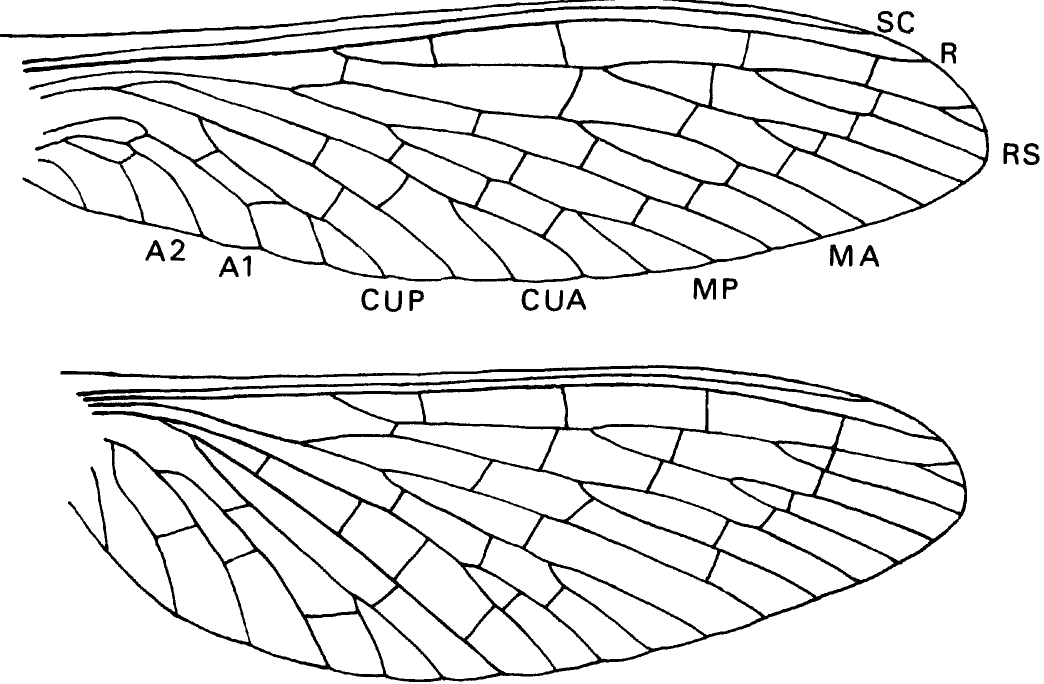

Figure 2. Eubleptus danielsi. Venational diagram of fore and hind wings. SC, subcosta; $R$, radius; $R S$, radial sector; MA, anterior media; MP, posterior media; CUA, anterior cubitus; CUP, posterior cubitus; $A 1$ and A2, anals. Drawing based mainly on specimen PH15 Paul Harris collection, with some details from specimens PE32046 and PE32045.

the specimen in 1965 only the reverse half could be found ${ }^{3}$ Having now examined many additional specimens, I am convinced that both Handlirsch and I incorrectly interpreted several of the vaguely indicated structures in the type. Most of the cross veins that I described and figured are obviously wrinkles in the wing membrane; in the well-preserved specimens discussed below the cross veins are as strongly developed as the longitudinal veins. Also, the structures that I considered to be pronotal lobes are, in part, the large eyes to which Handlirsch referred. The pronotal lobes are indeed present but they are small.

Handlirsch's Athymodictya parva, described in 1911 from a single, poorly preserved specimen (YPM18ab) in the Peabody Museum

${ }^{3}$ According to the records of the National Museum, counterparts of some of the Daniels specimens were kept by Mr. Daniels after Handlirsch had studied them; their present location is unknown. 
at Yale University, is without question a synonym of danielsi. Handlirsch mentioned a fine archedictyon on the wings and he placed the insect in the family Dictyoneuridae, but I can find no suggestion of it in the fossil. The matrix of that particular concretion is unusually granular and I surmise that Handlirsch interpreted the granulation as an archedictyon. If the fossil is moistened with alcohol, the characteristic cross veins of Eubleptus are discernible. The venational pattern, even as shown in Handlirsch's drawing, is identical with that of danielsi, although his figure incorrectly depicts some of the veins with pectinate instead of dichotomous branching. The type of parva is about the size of that of danielsi, the fore wing being 13 $\mathrm{mm}$. long, with a maximum width of $4 \mathrm{~mm}$.

\section{Specimens of Eubleptus danielsi Studied}

I have been able to examine seventeen specimens of danielsi during this investigation. For convenience of reference, $I$ include here an annotated list of these: 4

1. National Museum of Natural History, Washington, No. 38731 (reverse half only). Mazon Creek. Holotype of danielsi. Poorly preserved, showing about three-fourths of a fore wing, but virtually nothing of the body and hind wing. Fore wing, as preserved, $13 \mathrm{~mm}$. long.

2. Peabody Museum of Natural History, Yale University, No. 18. Mazon Creek. Holotype of Athymodictya parva. Poorly preserved, showing proximal portions of fore and hind wings, as well as pronotum, pterothorax, and parts of abdomen.

3. Paul Harris collection, no. PH15. Pit Eleven. Excellent preservation of entire insect, except end of abdomen; the best specimen known. Especially good are the wings (which include the color markings), the pronotum, and the head, which shows the antennae, and eyes, and the location of the beak.

\footnotetext{
4There are apparently only two exposures of the Francis Creek Shale at which specimens of danielsi have been found: Mazon Creek, the bed of the stream about 4 miles west and a mile north of Coal City; and Pit Eleven, a strip mine of the Peabody Coal Co., in Will and Kankakee Counties, Illinois.
} 


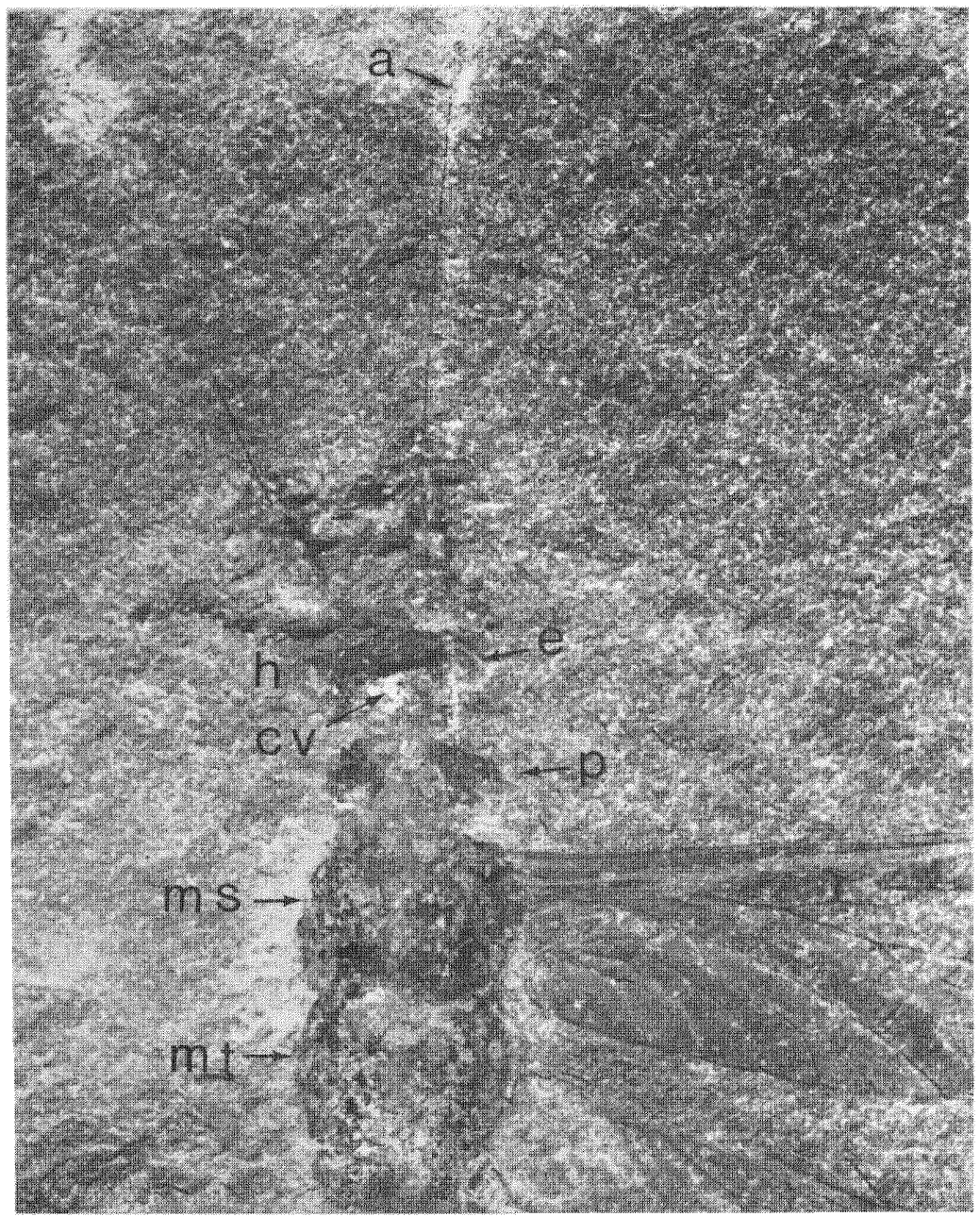

Figure 3. Eubleptus danielsi. Photograph of specimen PH15 (obverse), Paul Harris collection. Dorsal view of head and thorax; a, antenna; h, head; e, eye; p, pronotum; $\mathrm{ms}$, mesonotum; mt, metanotum; cv, small cavity in the matrix of the concretion, several millimeters deep and partially filled with kaolinite; cavity originally occupied by the beak. Width of mesonotum, $3 \mathrm{~mm}$. 


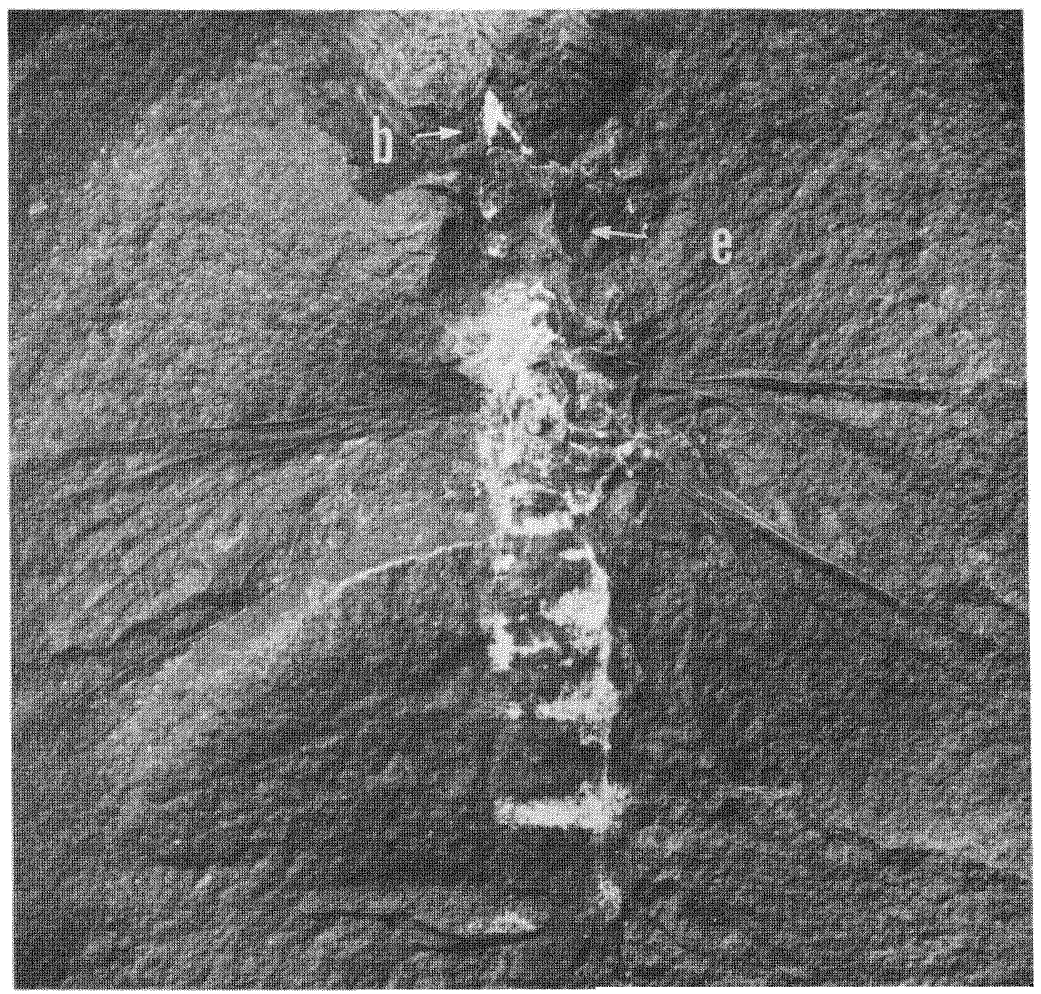

Figure 4. Eubleptus danielsi. Photograph of specimen 236, Daniel Damrow collection; dorsal view of thorax, but frontal view of head: $b$, beak; e, eye. The three thoracic segments are partially covered by kaolinite. Maximum width of fore wing in photograph, $3.5 \mathrm{~mm}$.

4. Field Museum, No. PE32046 (J. Herdina collection, no. H424). Pit Eleven. Very good preservation of all wings, especially of basal parts; also, thorax and abdomen, including proximal part of cerci. Head crushed.

5. Field Museum, No. PE32045 (J. Herdina collection, no. H540). Pit Eleven. Good preservation of basal parts of all four wings; body very poorly preserved.

6. Francis and Terri Wolff collection, No. 229. Pit Eleven. Good preservation of basal portions of all wings; poor preservation of body, but good view of head from above; one fore leg present. 


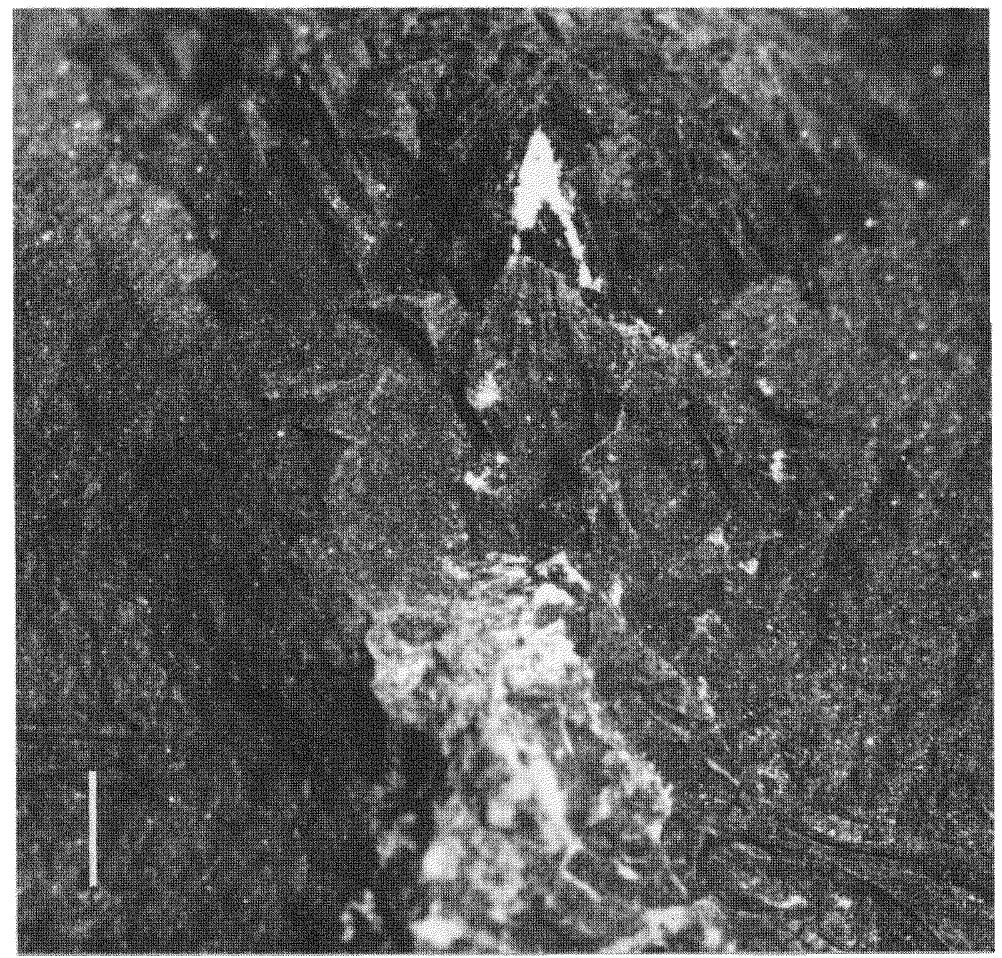

Figure 5. Eubleptus danielsi. Photograph of head of same specimen shown in figure 4, with greater magnification and different illumination. Scale line is $1 \mathrm{~mm}$ long.

7. Francis and Terri Wolff collection, No. 233. Pit Eleven. Good preservation of basal two-thirds of wings; most of body not preserved.

8. Raymond Bandringa collection, No. 66-PBSM-11-(3). Pit Eleven. Good preservation of basal parts of wings, part of antennae, eyes, and thorax.

9. Field Museum collection, No. PE22016 (from Dwayne Stone collection). Pit Eleven. Excellent preservation of whole insect in lateral view; wings overlapped but venation clear; shows abdomen, including cerci; head, including eyes; beak, in side view. 
10. Daniel Damrow collection, No. 236. Pit Eleven. Good preservation of basal part of wings; thorax strongly compressed; entire head well preserved in front view, showing beak, with excellent preservation.

11. Joseph Pohl collection, No. MPH8. Pit Eleven. Good preservation of basal parts of all four wings, with general features of body.

12. Helen and Ted Piecko collection, No. 402. Pit Eleven. Fair preservation of basal parts of all wings, but body not clear.

13. Helen and Ted Piecko collection, No. 422. Pit Eleven. Good preservation of most of all four wings and parts of thorax and abdomen.

14. Helen and Ted Piecko collection, No. 432. Pit Eleven. Fair preservation of body and of basal portions of all wings.

15. Helen and Ted Piecko collection, No. 436. Pit Eleven. Poor preservation of wings and body.

16. Richard Rock collection, no. 729. Pit Eleven. Good preservation of body and of basal parts of fore and hind wings.

17. Richard Rock collection, No. 817. Pit Eleven. Good preservation of basal parts of wings, poorly preserved body.

A composite drawing of Eubleptus danielsi is given in figure 8. The general habitus of the insect, as drawn, is based on the Paul Harris specimen, PH15 (see figures 3 and 4), but details from other fossils have been added, as follows (the numbers refer to the specimens in the above lists): head, PE22016, Wolff 229, Damrow 236; beak, PE22016, Damrow 236; pronotum, YPM 18; mesothorax and metathorax, PE32046, YPM18; fore leg, Wolf 229; abdomen, PE32046, PE22016; ovipositor, PE22016; cerci, PE32046,PE22016; wings, PE32046,PE32045, Wolff 229, HTP 422. All structures shown in the composite drawing are present in one or more of the fossils studied. ${ }^{5}$

\section{Discussion of the Structure of Eubleptus danielsi.}

Head: The head of danielsi was obviously hypognathous. In the specimens preserved in dorsal view (i.e., PH15, figure 2) there is a distinct hole in the matrix, at about the center of the insect's head, marking the point at which the beak penetrated the matrix; and in

\footnotetext{
'Handlirsch's restoration of Eubleptus, based on the unique type (1920), bears little resemblance to the insect in this cornposite drawing.
} 


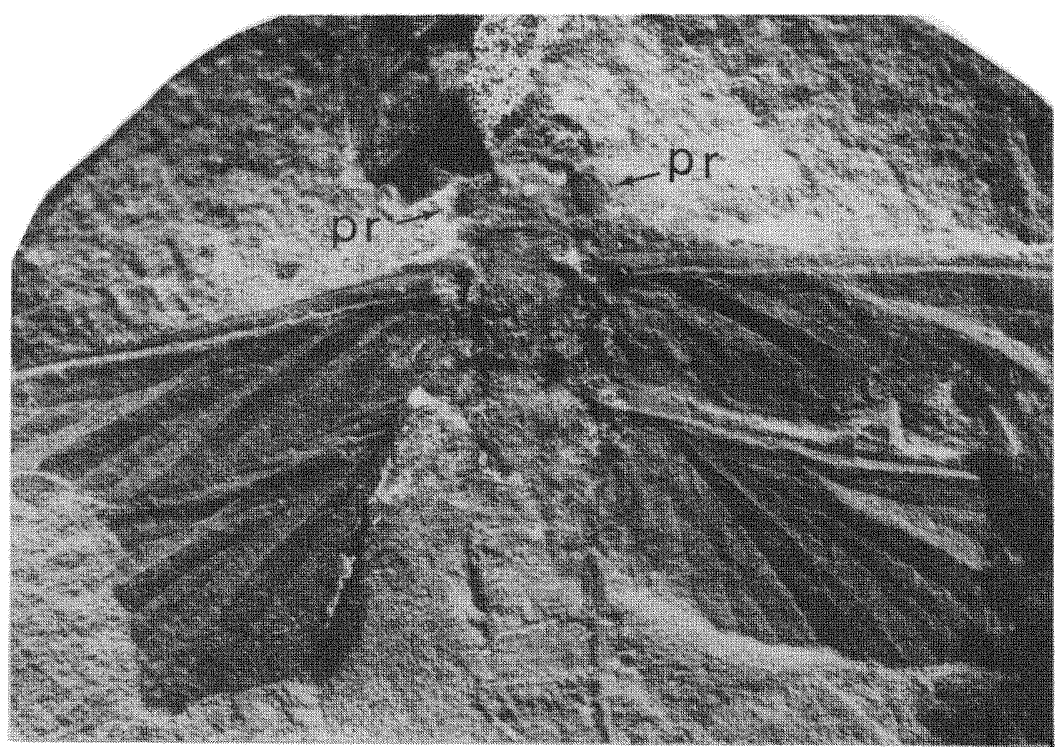

Figure 6. Eubleptus danielsi. Photograph of specimen YPM18 (holotype of Athymodictya parva Handlirsch. Dorsal view (reverse); pr, pronotal lobes. maximum width of left fore wing in photograph, $4 \mathrm{~mm}$.

the one specimen preserved in lateral view (PE22016, figures 4 and $5)$ the head is clearly hypognathous. The antennae are extraordinarily long and thin (PH15, Wolff 229; Bandringa specimen 66PBSM); for most of its length it is $.04 \mathrm{~mm}$ in diameter and the segments are about $.1 \mathrm{~mm}$ long. The antennae of PH15 include about 110 segments and are almost certainly complete. The beak, as preserved in lateral view in PE22016 is $3 \mathrm{~mm}$ long and slender; several stylets project from its end. In specimen Damrow 236, the beak is $2.8 \mathrm{~mm}$ long and as seen in front view (figure 4) is triangular in shape, relatively broad basally, and bears long striae, as has been noted in other species of Palaeodictyoptera (Kukalová, 1970). The eyes are large and bulging, as shown in PH15, Wolff 229, Bandringa specimen 66-PBSM, and especially in PE22016, in which the eye, in lateral view, is preserved in strong relief.

Thorax. The prothorax is very small and, as Handlirsch showed in his drawing of parva, bears small lateral lobes about $1 \mathrm{~mm}$ wide (YPM 18); the folded and twisted condition of the lobes in some specimens suggests that they were thin and weak. The legs ae known 


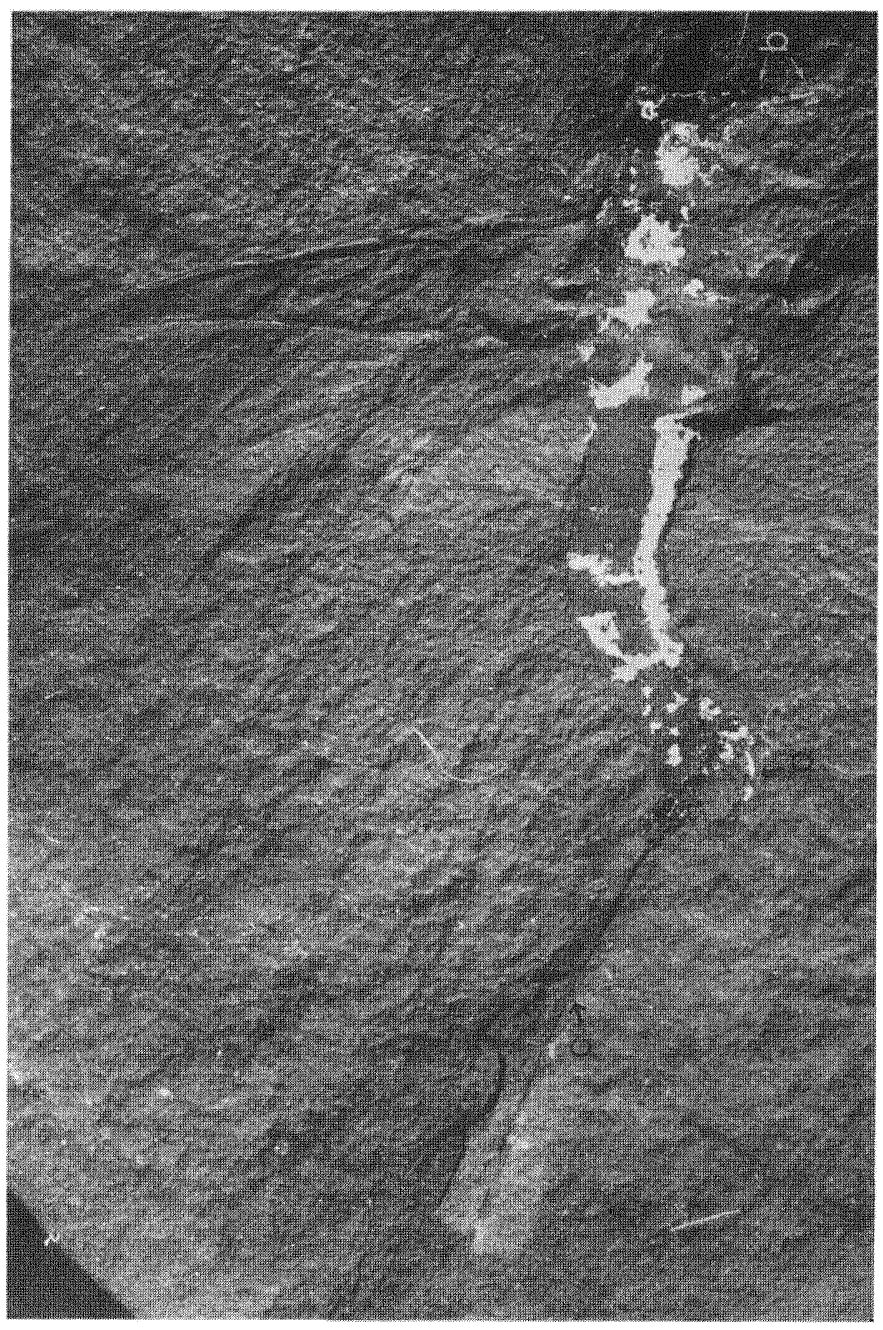

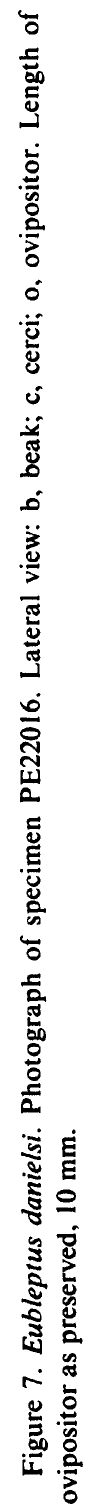


only from a single fore leg in Wolff 229; the preserved part, apparently consisting of the femur, tibia, and tarsus, has a total length of $3.5 \mathrm{~mm}$; the tarsus appears to have five subequal segments. The wing venation, as previously noted, shows only a slight amount of variation among the 17 specimens examined. The shape of the wings is more diverse, but that has undoubtedly been determined to some extent by the process of preservation and the amount of movement of the sediment in which the specimens were entombed. The degree of variation in wing shape in the specimens of danielsi seems to be comparable with that reported by Kukalová-Peck (1971) for the Permian Dunbaria fasciipennis. The wing markings, consisting of four triangular spots along the anterior margins of both wings, are similar in both specimens in which they are preserved (PH15 and PE32046).

Abdomen. The segmentation of the abdomen is nearly homonomous, except for the 9 th and 10th segments, which are slightly smaller than the others. The lateral margins of the tergites are extended posteriorly only slightly (YPM18), about as in the Spilapteridae. The ovipositor, preserved only in PE22016, is strongly curved and only $2.5 \mathrm{~mm}$ long, not extending beyond the end of the abdomen. The cerci (PE22016, and PE32036) are preserved to a maximum length of $10 \mathrm{~mm}$, but since they end at the edge of the concretion, that is almost certainly not their full length. Segmentation of the cerci is clear at intervals; the segments are $.3 \mathrm{~mm}$ long (beyond the basal segments) and $.3 \mathrm{~mm}$ wide, and covered with short hairs. The largest piece of a cercus includes about 34 segments.

\section{Relationships of Eubleptus}

Study of the new specimens of Eubleptus danielsi provides no evidence to justify the recognition of the order Eubleptidodea. On the contrary, all the evidence supports Handlirsch's assignment of the family Eubleptidae to the Palaeodictyoptera. Furthermore, both the wing venation and the newly acquired knowledge of the body structure of Eubleptus show a close relationship to the family Spilapteridae of the Palaeodictyoptera. The wings of Eubleptus have the same general shape as those of the spilapterids, the hind wings being slightly broader than the fore wings. The only significant difference between the venational patterns of the two families is the reduction of CUA in the family Eubleptidae: it has only a small 


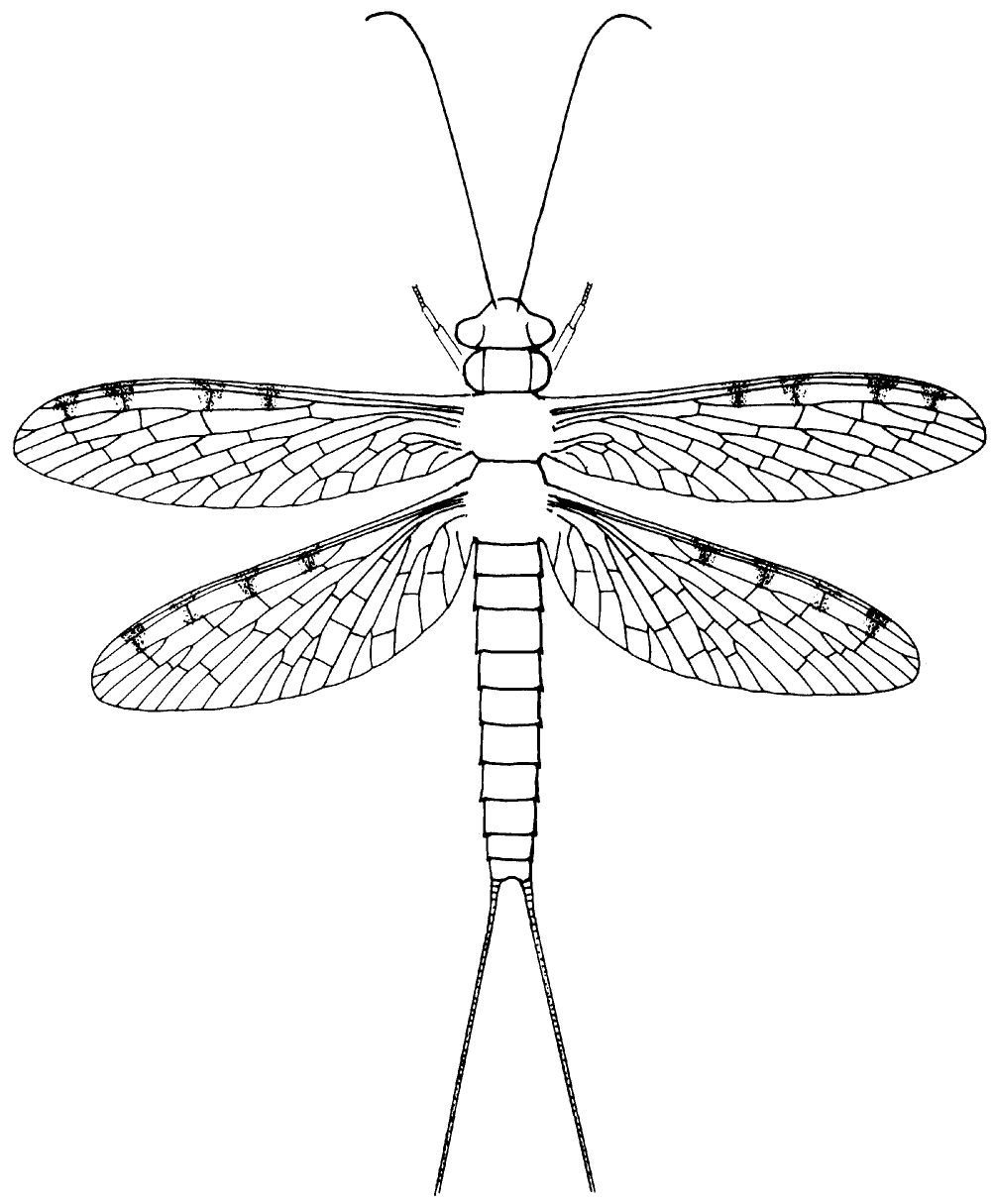

Figure 8. Eubleptus danielsi. Reconstruction based mainly on specimen PH15, in the Paul Harris collection, with some details from specimens PE32046,PE32245, PE22016, YPM18, USNM35576,FTWolff 229 and 233, HTP 422, and Bandringa 66-PBSM. All structures shown are preserved in at least one of these fossils. Length of fore wing, $13 \mathrm{~mm}$. 
terminal fork, whereas in the spilapterids CUA has several long branches. This difference serves to justify the separation of Eubleptus into its own family, but does not have any significance at the ordinal level. The body structure of Eubleptus turns out to be very similar to that of the spilapterids. The pronotal lobes are small in both, the beaks are relatively small and of similar shape in both, the legs (so far as they are known) are short in both, and the ovipositors are similarly formed. Eubleptus danielsi is the smallest known species in the Palaeodictyoptera, but it is not much smaller than the Permian Dunbaria fasciipennis of the family Spilapteridae.

\section{Literature Cited}

Carpenter, F.M.

1965. Studies on North American Carboniferous insects. 4. The genera Metropator, Eubleptus, Hapaloptera and Hadentomum. Psyche, 72: 175190.

HANDLIRSCH, ANTON

1906a. Revision of American Palaeozoic insects. Proc. U.S. Nat. Mus., 29 (1441):661-820.

1906b. Die fossilen Insekten und die Phylogenie der rezenten Formen. II. Abschnitt: Palaeozoische Insekten, p.53-393. Engelmann, Leipzig.

1911. New Paleozoic insects from the vicinity of Mazon Creek, Illinois. Amer. Journ. Sci. (4) 21:297-326,353-377.

1920. Paläontologie, in Handbuch der Entomologie (ed. C. Schröder). 3:117-306.

Kukalová-Peck, J.

1971. The structure of Dunbaria (Palaeodictyoptera). Psyche, 78: 296-305. Laurentiaux, D.

1953. Classe des insectes. In Traité de Paléontologie (ed. Piveteau), p. 397-527. MARTYNOV, A.V.

1938. Etudes sur l'histoire geologique et de phylogenie des ordres des insectes. Trav. Inst. Paleont., Akad. Nauk USSR, 7 (4):1-148.

ROHDENDORF, B.B.

1962. Osnovy Paleontologii: Tracheata, Mandibulata. Akad. Nauk USSR., p. 1-374. 

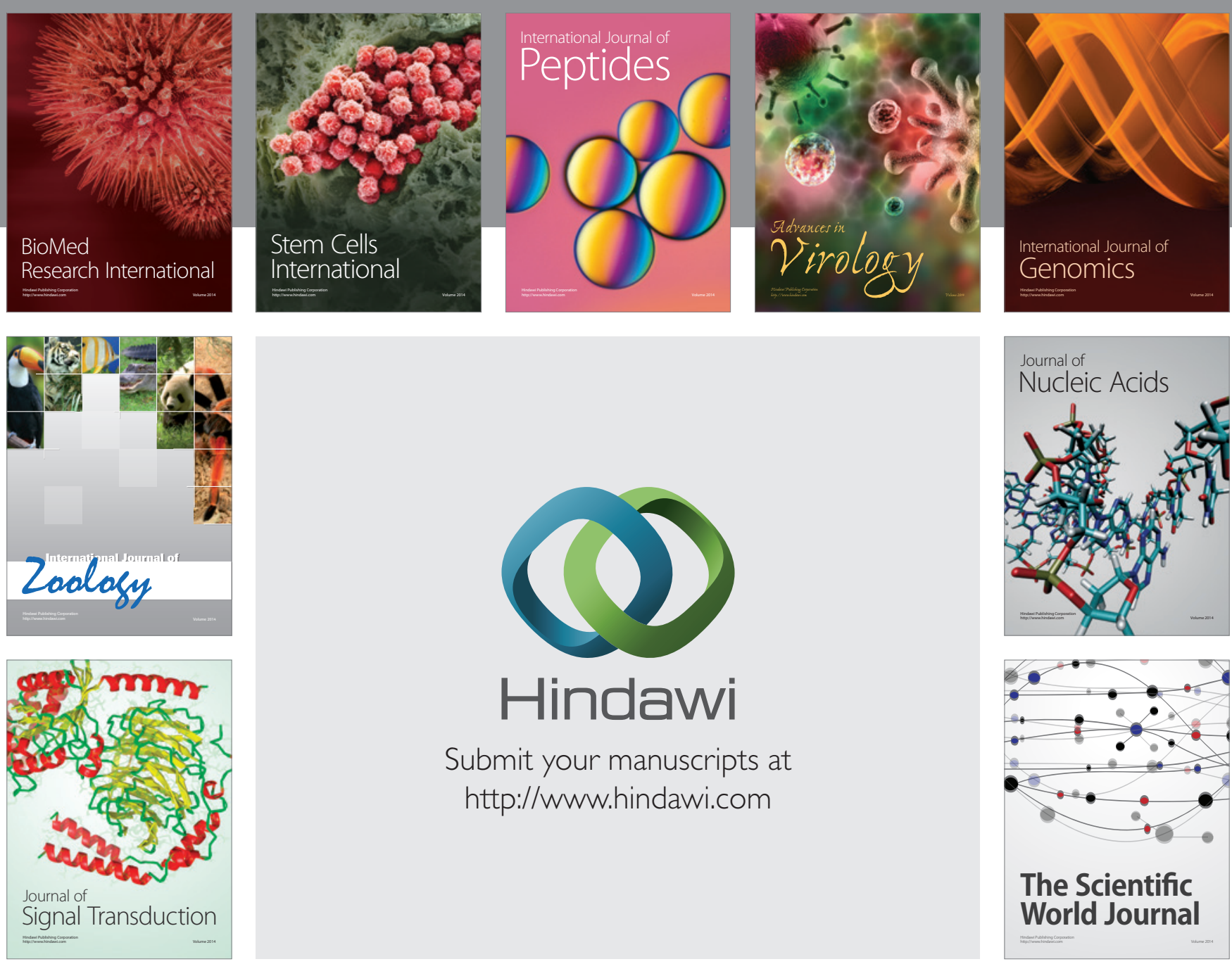

Submit your manuscripts at

http://www.hindawi.com
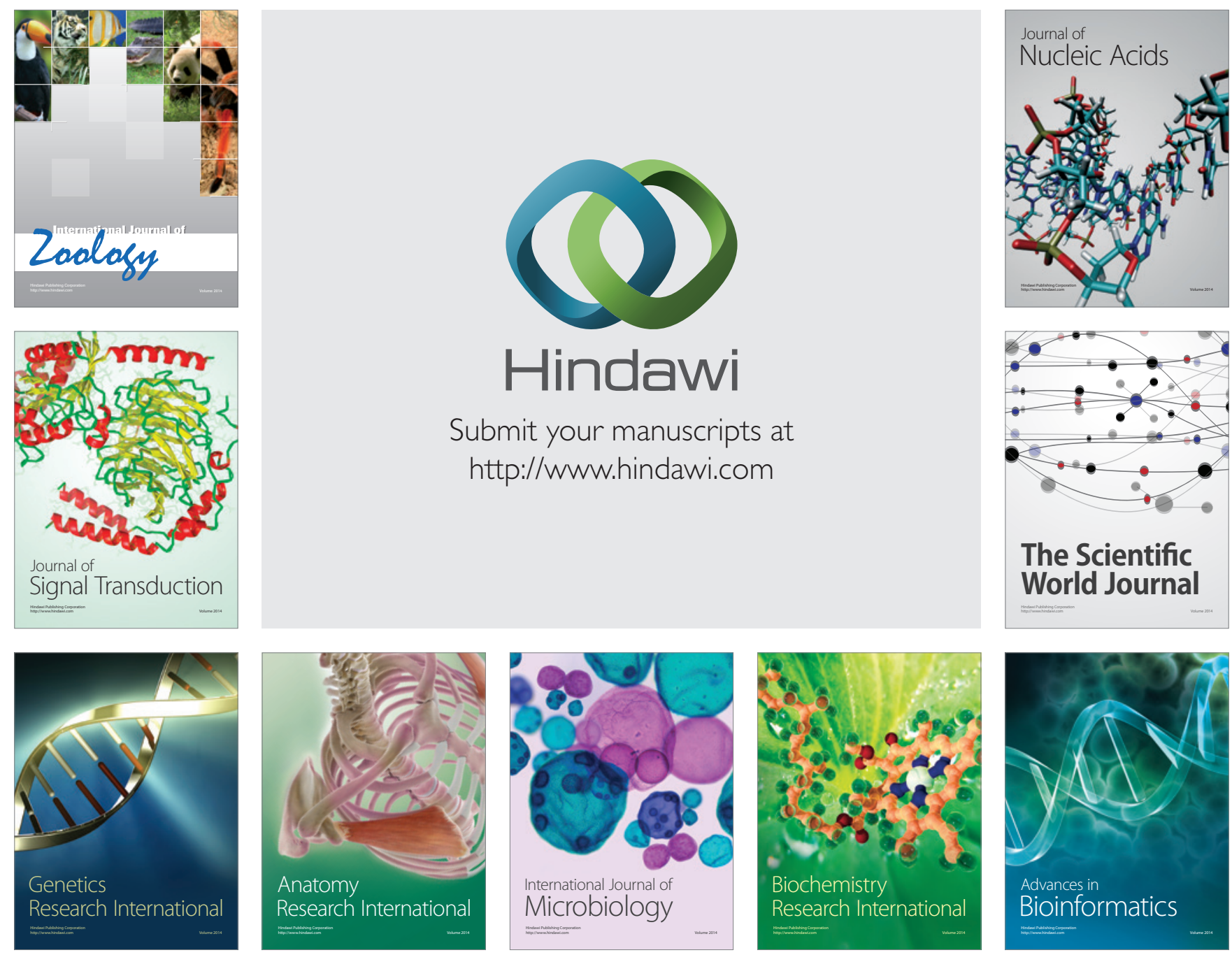

The Scientific World Journal
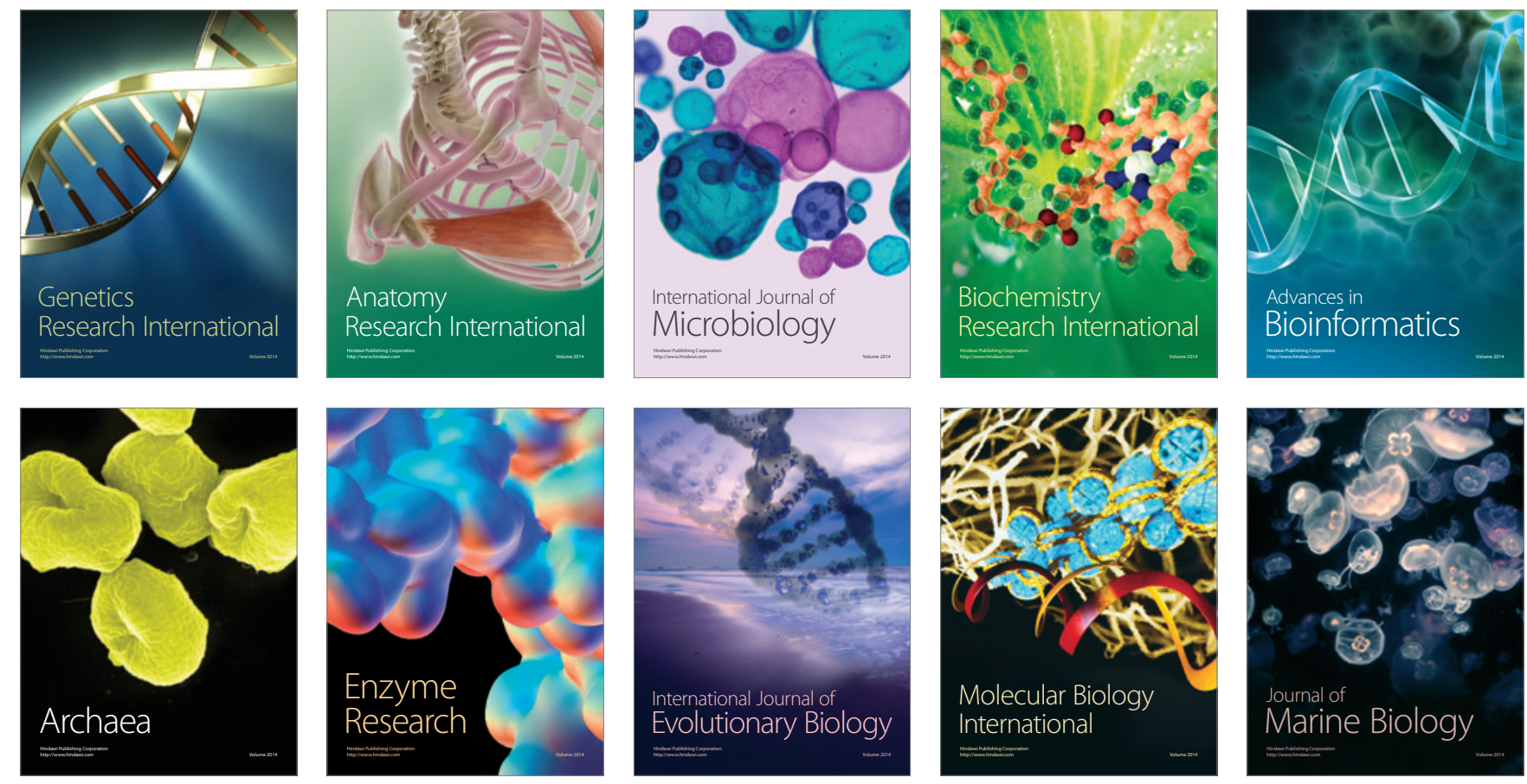